\title{
Analysis of The Scarlet Letter from the Perspective of Ecology
}

\author{
Ran Huo ${ }^{1}$ \\ ${ }^{1}$ Foreign Language Department, Zhengzhou University of Aeronautics, Zhengzhou, China \\ Correspondence: Ran Huo, Foreign Language Department, Zhengzhou University of Aeronautics, Zhengzhou, \\ China.
}

Received: October 31, 2021

Accepted: December 29, $2021 \quad$ Online Published: January 17, 2022

doi:10.5539/ells.v12n1p76

URL: https://doi.org/10.5539/ells.v12n1p76

\begin{abstract}
Nathaniel Hawthorne's The Scarlet Letter is "the culmination of his reading, study, and experimentation with themes about the subjects of Puritans, sin, guilt, and the human conflict between emotions and intellect" (Van Kirk, 2000, p. 7). Since its publication, the novel remains popular generation after generation and has been studied in myriad ways. Following environmentalist scholars Jeger and Slotnick, this paper studies Hawthorne's masterpiece through the lens of ecology, suggesting that study should be focused on the transaction between people and their settings, which includes both the natural and social environment, rather than looking exclusively at individuals or the environment as sources of human's health problems. From such an ecological perspective, this analysis of the story focuses on space not merely individuals. The understanding that place is not only land's natural features but also includes the cultures of the people with their human, social, and economic arrangements is essential. This paper also analyzes the reasons for the trauma of the four protagonists of The Scarlet Letter and the ways their destinies shaped by their different relations to their ecological environment. Finally, the paper illustrates the role nature and love play in promoting mental health and the overall growth of the main characters in the novel. In conclusion, the novel recognizes that the harmony between humans and their environment, both external and internal, and both natural and man-made, is key in enhancing people's happiness and health level, both physically and psychologically.
\end{abstract}

Keywords: ecology, trauma, nature, environment, acceptance

\section{Introduction}

Nathaniel Hawthorne, born July 4, 1804, enjoyed reading and making friends with books during his childhood. His fondest memories centered on the times he could run wild and fish all day long or practice shooting with an old fowling piece. All these experiences helped him produce his masterpiece The Scarlet Letter. According to the prominent Hawthorne scholar Van Kirk, the novel has remained popular since its publication "generation after generation because its beauty lies in the layers of meaning and the uncertainties and ambiguities of symbols and characters" (2000, p. 7). The novel has been adapted for the stage in many different times and with different emphasis, and both the novel and its most famous symbols, including the scarlet A, serve as part of the American people's national consciousness, even including those who have never read the book (Pennell, 2018, p. 7).

The story is set in the Puritan town of Boston, opening in 1642. Hester Prynne, a young and beautiful woman, gets exposed for committing adultery and must wear a dress with a scarlet " $\mathrm{A}$ " on her bosom as a permanent sign of her shame as a punishment. In several key scenes, holding her illegitimate baby, she is forced to stand on a scaffold with a crowd of townspeople gazing at her. In the crowd, her long-lost husband, Roger Chillingworth, seeing her shame, vows to take revenge on the baby's father. John Wilson, the old minister, and Arthur Dimmesdale, the minister of the church, plead with the adulteress to reveal the identity of the father, but Hester refuses to reveal his name. After Hester is released from prison, she moves into a cottage at the edge of town with her daughter Pearl and begins making her living with needlework. Pearl's real father, the Reverend Dimmesdale, lives life tormented due to his secret and unacknowledged guilt and over the course of the novel, his health declines. At the same time, Roger Chillingworth, Hester's husband, who had been absent for two years returns, acts as a doctor, and becomes an intimate friend of Dimmesdale, but never reveals his true relationship with Hester. Through his duplicity, Chillingworth enacts revenge on Dimmesdale continuously, in covert and subtle ways, psychologically manipulating on Dimmesdale and tormenting his fragile soul. His discourse with Dimmesdale increases Dimmesdale's inner agony and causes his physical deterioration. Observing all this, Hester believes she has the responsibility to help her former lover and true love, Dimmesdale. She persuades 
Dimmesdale to leave Boston secretly to start a new life in Europe. However, the sin is deeply permeated Dimmesdale's soul and he knows that he cannot escape his guilt and responsibility until he confesses his sin in public. Finally, towards the end of the novel, he climbs upon the scaffold and confesses his sin publicly, and then dies in Hester's arms. Chillingworth also dies shortly after the death of the minister, as he finds no purpose in life after the death of his victim. Chillingworth leaves Pearl a large amount of money, enabling her to go to Europe with her mother. Hester returns to Boston several years later with the scarlet letter still on her bosom, and becomes an angel in the townspeople's eyes for always providing help and generosity to all.

The novel made its author well-known and received warm reception and recognition both in America and abroad. It remains a hot subject for critics and still is studied and interpreted in various ways: the changing meaning of the symbol, the analysis of the theme, the structure, and the psychology of the characters, having all remained objects of debate and scrutiny. For example, Kaul, A.N. studies the novel in his article Character and Motive in the Scarlet Letter (1968). In his article, the author explores the novel from three dimensions: the examination of Puritan theology; Hawthorne's concept of sin and the literary technique. Kaul points out that Hester and Dimmesdale are frustrated not because they live in a certain kind of society, but because a certain kind of society still lives in them and rules invisibly their actions and destinies. Kilborne, B studies the novel in his article Shame Conflicts and Tragedy in the Scarlet Letter (2005). His paper demonstrates that different from most commentators who assumed Hester's pain to be shame-based, and Dimmesdale's pain to be guilt-based, Kilborne gives an interpretation that both are afflicted with shame, and Dimmesdale's shame is more unbearable because more conflictual, less representable. Chen, Yanchun studies it in On Arthur Dimmesdale's Double Personalities as Revealed in Hawthorne's the Scarlet Letter (2017). In Chen's article, it gives an analysis of the double personalities of Arthur Dimmesdale and the factors in shaping his double personalities. Chen's paper aims to help people have a better understanding toward this hypocritical person and a corrupt society. Wang, Yueming studies the novel in the article Misogyny or Feminism? A Probe into Hawthorne and His the Scarlet Letter (2017). Wang analyzes the doubt of Hawthorn's tendency for a misogynist or a feminist, and supports the idea in his article that Hawthorne has the tendency for feminism in his work as he mirrors Hester's life as his own, he honors a woman's rebelling against patriarchy and he has a beloved wife and mother. Among various studies of The Scarlet Letter, the major focus is on psychological analysis, structure analysis and the feminist methodology. This paper presents here argues for an ecological approach that centers on both the representations of nature and society in the text.

Ecology was first defined by Ernst Haeckel as "the whole science of the relationships between the organism and its environment" (cited in Zapf, 2016, p. 41). Ecology remains integrally linked with life, geographical location and their interrelations. Ecocriticism is "study of the relationship between literature and the physical environment", advocating an "earth-centered" approach to literary studies (Zapf, 2016, p. 41). In the past, when researchers studied literature, they tended to neglect the relationship of literature to nature and the text to the extra textual world or instead, they only studied literature as ideology. In fact, literary texts provide a transformative site of cultural self-reflection and cultural self-exploration (Zapf, 2016, p. 28). Currently, the ecological studies in literature are becoming one of the fastest-growing areas of study and there seem to be a growing number of people who recognize that the environment and humans are not independent from each other. Thus, as one ecological critic stresses, "the growing expansion of ecological consciousness translates into a deeper understanding of interconnectedness in both nature and history" (Snyder, 2004, p. 3). It's important to keep in mind that the environment is not only external, but also internal. "The inner worlds and landscapes of the mind, the psyche, the cultural imagination" (Zapf, 2016, p. 80) are also part of environment for humans and make up the cultural ecosystem. In literature, besides the study of the external environment, people also need to get into "the inner lives and psyches of our characters, with their obsessions, kinkiness, and secrets as well" (Snyder, 2004, p. 9).

Hawthorne's The Scarlet Letter provides a good but generally unrecognized example to show the interplay and interconnectedness between the environment, culture and people's mental health problems and well-being level. It also displays how the fictional neighborhood in Puritan Massachusetts mistreats Hester and Pearl, and readers discover that a lack of social support deeply shapes personalities of the victims, particularly the development of Pearl, who cannot be blamed for the allegedly sinful actions of her mother. Fortunately, she finds solace in the wild and the natural environment, which offers her nourishment and comfort, and helps all of the characters alleviate stress and anxiety and find connection and belonging in the environment.

\section{A Place-Centered Perspective Versus an Individual-Centered Perspective}

To study literary works from the perspective of ecology means to study communities, environments and social systems when we analyze the texts. According to behavioral ecology, people's mental health problems often stem 
from the transaction between people and their settings. Individuals' behavior should be taken as a production of the larger society instead of exclusively the result of autonomous units acting within environments (Jeger \& Slotnick, 1982, p. 4). People act on their environments, just as environments influence people. Humans and nature remain interdependent and form an integrated whole, even if this truth has remained insufficiently recognized in traditional literary and social criticism. The environment is not isolated and separated from humans. The natural environment changes through the man-made environment with its accompanying social and cultural norms.

As some critics explain "we argue that all literature has and reflects place, humans as well as environments in relation to each other" (Waldron \& Friedman, 2013, p. 9), and The Scarlet Letter is no exception. When we interpret the fate of characters in the novel, we must explore the significance of the places where individuals find themselves because characters and places are complexly interwoven. Place has been defined as "an open and interconnected region within which other persons, things, spaces and abstract locations, and even one's self, can appear, be recognized, identified and interacted with" (Waldron \& Friedman, 2013) and therefore place, as it has been argued, "must be considered through multiple dimensions that weave its physical and social ecologies together-economic, political, cultural, religions, but also geographic, environmental, biotic and spatial" (Waldron \& Friedman, 2013).

To return to The Scarlet Letter, Hester Prynne finds herself punished and humiliated publicly as she is forced to stand on a public scaffold with the scarlet letter A for adultery on her bosom for three hours. She also receives the command that she must wear the shameful symbol for the rest of her life. The townspeople say evil and harsh words about her. We read of townspeople insulting her by saying: "At the very least, they should have put the brand of a hot iron on Hester Prynne's forehead"; "This woman has brought shame upon us all, and ought to die" (Hawthorne, Pennell ed., 2018, p. 82). They are irritated by Hester's beauty and elegance and also the fantastically embroidered scarlet A. Dimmesdale, however, the lover and real father of the baby, will not leave his home in heart and go to a new place to find freedom and peace even if his health declines and he suffers from guilt and psychological despair since he must hide his crime and watch Hester suffer publicly. All the characters suffer due to the time and place that shapes the common values, namely, the Puritan community in 17th century Boston with its beliefs, practical life and assumptions about acceptable behavior.

The scene of the novel is 17th century Boston in the Puritan society, where the dark color from the prison, in the middle of the town, dominates and creates a feeling of unwavering sternness and rigidity. Van Kirk says "The Puritan village with its marketplace and scaffold is a place of rigid rules, concern with sin and punishment, and self-examination" (2000, p. 96).

The first settlers who came to establish colonies in America from England in the early 17th century gave up the security of their homes, their occupations, and their communities in hopes of increasing their wealth and status and for the right to practice their particular strict religious framework. "Many who opted to make the journey to Massachusetts Bay were deeply motivated by their religious beliefs. As such, they intended to establish communities in which their religious sensibility would inform governance, law and social relations" (Pennell, 2018, p. 22). Based on the Puritans' understanding, they believed that in proper model communities, church and state must be firmly linked and closely interrelated. At the time we first see Hester on the scaffold in Boston in 1642, historians note "the conflicts between the king and Parliament had become irreconcilable and in August of the year, civil war erupted" (Pennell, 2018, p. 26). The third scaffold scene in the novel, readers learn, is set in 1649. Interestingly, this was the year in England when Charles I was beheaded just one month before Hawthorne's scene is set. Considering the historical events taking place in the land from which they came, it makes sense that, the Puritans have anxieties about their community's stability and the future of their religious values, which are under threat across the ocean. Thus, the novel legitimately depicts the harshness and strict policy towards the violators who broke rules.

Among all the crimes in Puritan Boston, the setting of the novel, the major capital offenses that were strictly punished include "murder, witchcraft, idolatry, blasphemy, sodomy and rape, as well as adultery" (Pennell, 2018, pp. 30-31). In Hester's case, the magistrate thought her too young and beautiful to have initiated the sin. Besides, she has reason to believe her husband may have died at the sea; the local authorities don't enforce her punishment with the full severity of their law. For example, they chose not to put the brand of a hot iron on her head.

Puritan communities favored educated clergy, usually with a university degree, to provide guidance to their congregations in reading and interpreting the Bible's meaning and to be church leaders. Dimmesdale seems the right man who can meet all the criteria and therefore serves as the chosen religious man. As the loyal servant of 
God, he believes humans are depraved and can do nothing to help themselves toward salvation. Only God has the right to decide who will be saved. Thus, he can't forgive himself through any level of good work he performs and therefore he feels trapped in his sins.

It is this cultural environment, an attitude devoid of mercy from both the local government and townspeople, dooms Hester and Dimmesdale to their fate. Human dwellers and cultural institutions interact with each other and no individual can escape from the environment. They are all interwoven and interconnected.

\section{The Reasons for Trauma of the Protagonists and Their Destinies}

Trauma has been and is a part of human life and history both in its everyday and its extreme and spectacular forms, and it involves experiences of fear, terror, and disempowerment that overwhelm the defenses and threatens to paralyze vital functions of a person or a community (Zapf, 2016, pp. 207-208). Trauma studies are characterized by a broad diversity of concepts, subjects, approaches and directions for trying to heal trauma (Zapf, 2016, p. 207). In The Scarlet Letter, trauma means the psychological stress which produces negative feelings and behavior. The reasons for trauma from the ecological perspective lie in the disconnection and alienation between humans and their environment, the mind and the body, the self and others, and a division between the culture and nature. We need to position trauma within a larger culture, which influences individual consciousness and personal communication.

\subsection{The Trauma for Hester Prynne and Her Fate}

Hester Prynne suffers immensely from the public humiliation and isolation within Puritan society. Her alienation and disconnection from her environment are the results from the mistreatment given to her by the neighborhood due to her public sin and her violation of Puritan practices. The neighborhood is the important social unit, and it inescapably can affect the social conditions of individuals living within it. "The lack of formal or informal supports in neighborhoods may lead to feelings of social isolation among families but may only lead to maltreatment during times of family crisis (Belsky, cited in Freisthier, 2006). Hester stands on the scaffold alone with her child. The absence of the father of the child already represents a kind of family crisis. Because of the scarlet A on her chest, she embodies a general symbol everywhere she goes. She symbolizes a woman who, whether intentionally or not, rebels against unnatural rules of sexual repression. Though her delicate needle work has been accepted in many cases, it is "not recorded that, in a single instance, her skill was called in aid to embroider the white veil which was to cover the pure blushes of a bride" (Hawthorne, Pennell ed., 2018, p. 109). Nowhere can she find friendship, acceptance or a community she can belong to. When she passes the town, the children even pursue her at a distance with shrill cries, acting cruelly. Every time new people arrive, their curious gaze at the scarlet letter functions as a peculiar torture for her and brands it afresh in her soul.

Lack of resources, social support and increased feeling of isolation in the neighborhood transforms Hester from a beautiful, elegant, and passionate young lady into a poor, fatigued woman with a seemingly empty soul.

However, Hester is a person with strength, and she is a survivor in the end. She chooses to reach out to others despite her shame, and this choice helps her and everyone. Despite her loss of acceptance in her place, her identity and normal connections with her community, which create chronic stress and make her feel helplessness and despair, her ability continually to love others and help the community that rejects her paradoxically endows her with much strength and a sense of belonging. The novel makes clear that over time, the community changes more than Hester and finally even changes the meaning of the scarlet A and that change saves her from alienation. Even though she lives on a meager income from her needle work, she donates her extra money to charity to help those suffering. In the face of constant insults and prejudice against her from her neighborhood, she "never responded to these attacks" and she "was patient, - a martyr" (Hawthorne, Pennell ed., 2018, p. 111). During her long-time suffering, "there was neither irritation nor irksomeness. She never battled with the public, but submitted uncomplainingly to its worst usage" (Hawthorne, Pennell ed., 2018, p. 169). Her consistent intolerance and love gradually overcome townspeople's hatred and even transform their feelings for her into love. As an outcast of society, she finally finds herself invited into the household that are darkened by trouble. After the death of Dimmesdale, she leaves the town and returns many years later after, "the scarlet letter ceased to be a stigma which attracted the world scorn and bitterness, and became a type of something to be sorrowed over, and looked upon with awe, yet with reverence too" (Hawthorne, Pennell ed., 2018, p. 244). After so many toilsome and devoted years, she eventually establishes connection with the community and finds her self-definition and sense of belonging and gains her salvation by herself.

\subsection{The Trauma of Arthur Dimmesdale and His Fate}

Arthur Dimmesdale, Hester's real love and the father of Pearl, serves the community as a well-educated Puritan 
minister, who devotes his life to God and remains passionate in his religion. His trauma lies in the disconnection between his body and soul, his external reputation and his internal sins. He contains "a great wealth of interior life, a private and secret life" (Becker \& Ernest, 1971, p. 46). He somewhat splits into two, the self and the body, the one hidden, the other open.

In the townspeople's eyes, Dimmesdale appears sacred and maintains a high status. Because he suffers from inner guilt, he weakens as the novel unfolds. However, his popularity among the congregation grows stronger. People admire him for his eloquence and moving sermons, an admiration that seems ironic given his hidden nature. On the outside, he seems to crave recognition and power and his status as the spiritual leader of the community is high. He clearly knows the contradictions of his life and value system, yet feels morally obligated to act in moral ways, even while realizing that he suffers from his hypocrisy. However, his inner world and inner turmoil over his misguided sense of responsibility (he believes he must maintain a religious, holy, saint-like façade) has more power and authority over his psyche than does the visible positive image he presents. His self-torture and self-punishment condemns his health and leads to physical failure. People "deemed the young clergyman a miracle of holiness" (Hawthorne, Pennell ed., 2018, p. 244). Despite his inner truth, in sharp contrast to what seems should prevail, the more he is worshipped, the more his inner soul struggles. The more others view him as a saintly, wise, holy man, the more he suffers while paradoxically feeling the necessity to maintain such appearances. This pretense doesn't serve his vanity or self-respect; it undermines it and his choice to conceal his adultery with Hester ultimately causes him more suffering. But he feels by maintaining a pure façade he serves the cause of promoting the religion rather than his own inner truth. He tries many times to speak his truth and confess his paternity and establish an equilibrium between his inner life and outer appearances- to allow the inside to come out- but every time he fails, and his inner world remains isolated and blocked off by his exterior façade.

Chillingworth's revenge, taking the form of a pretended friendship and counsel, actually provokes and deepens Dimmesdale's agony and makes Dimmesdale weaker and more pained as he increasingly doubts his self-worth. How can what Dimmesdale views as his ruined, polluted soul offer redemption and purification to other souls. He perceives if his true nature were known, he would fail to be able to help others. Hester, on the other hand, tries to convince him to leave and go to a new place to start over and find his freedom and happiness. But as one critic Van Kirk, argues, "no matter how hard he has tried, he cannot outrun the truth that his conscience and his mind believe. Sailing to Europe will not bring him beyond the reach of God's knowledge" (2000, p. 72). If he does not confess his part in the sin, he can never be at peace with Hester or his tortured conscience, no matter how far away he sails or how long he may live.

Eventually, by the end of the novel, he learns the failure of his pretense morally and he chooses the right thing to do, which means revealing his real behavior. In the last moments of his life, he "has come to a resolution of his problems through love that leads to confession and absolution" (Harper, 2000, p. 63). Through revealing his nature as the lover of Hester and the sinner he is, he then finds real connection, happiness and absolution because his body, his soul, and his open love and acknowledgment of his family actually redeem him, leading to true forgiveness and joy. Only by rejecting his previous choices can he accomplish real fulfillment. Thus, his life becomes more complete, and unified, and all the boundaries between him and the environment collapse. His story cycle "begins and ends with the moments in which death is given meaning through the construction of social relationships" (Waldron \& Friedman, 2013, p. 76).

\subsection{The Trauma of Roger Chillingworth and His Fate}

Roger Chillingworth, Hester's husband, who, as the story begins, is believed dead at the bottom of the sea, is also a victim due to the disconnection with his loved one and his toxic method of dealing with his trauma.

When the misshapen man comes to Boston after years of pursing of knowledge, he sees his wife, Hester Prynne, "standing up, a statue of ignominy, before the people" (Hawthorne, Pennell ed., 2018, p. 101). He believes he has lived in vain, and the world is cheerless for him. Feeling alone, he longs to kindle a household fire. He had drawn Hester into the innermost chamber of his heart and had dreamed of seeking warmth, but ultimately found only the darkness of scandal. He had once been calm in temperament, kind, pure and upright, but had now transformed into a devil and his only drive is to seek revenge on the baby's father. The process makes him an evil man and a fiend. He devotes himself for seven years to the constant analysis of a heart full of torture and derives his enjoyment thence, and adds fuel to those fiery tortures which he analyzes and gloats over (Hawthorne, Pennell ed., 2018, p. 177). His face also changes from meditative, scholar-like to something ugly and evil.

All his deformed happiness derives from his torment of Dimmesdale, and that is the way he builds his unhealthy and abnormal connection with the environment. Once Dimmesdale confesses to his sin and escapes from his 
grasp, he realizes he has no reason to live without his victim. All his strength and energy desert him, and there is no further material to support his evil principle and no more devil's work on earth for him to do. Having lost his reason to live, he dies within the same year after the death of Dimmesdale. Eventually, "humans are thrown into lives of meaning through relationships, that is, the process of finding meaning, coherence, and wholeness through relational views and practices" (Escobar, 2008, p. 154). Without relationship, destruction follows.

\subsection{The Trauma of Pearl and Her Fate}

Pearl functions as the symbol of adultery, both in the fictional community and for the novel as a whole. She also serves as a character who represents love and passion. She looks quite beautiful, but she also possesses a somewhat absurd and even disturbing personality due to her trauma. When she is born, she isolates with her mother. The novel tells readers, "Never since her release from prison, had Hester met the public gaze without her" (Hawthorne, Pennell ed., 2018, p. 117). No doubt, this stigma, prejudice and discrimination leveled against her and her mother harms the little girl in unseen ways. According to ecological theory, people need human connection to survive (Downey \& Feldman, cited in Downey \& Daniels, 2020). When youth experience multiple forms of devaluation by a community, they inevitably face increased exposure to harmful childhood circumstances, thus, they are likely to generate a sense of inferiority and become deeply sensitive or alternatively develop a deep dissociation from other children. As she lacks any easily available support system, (except her mother), which excludes deep relations with family, close friends, neighbors, or other community groups, her irrational behavior follows logically. "The child could not be made amenable to rules. In giving her existence, a great law had been broken." (Hawthorne, Pennell ed., 2018, p. 114). Sometimes, Pearl shows emotions that seem inappropriate for her age. At times she seems wiser than her years; at others she seems developmentally and socially held back. When she reaches an age where she becomes capable of normal childhood social interactions, she never achieves normalcy. She fails to mingle with the other childish voices, as she is born an outcast of the world of infants and she has no right to converge with the Christian infants. She plays with natural objects, but she only creates imaginary enemies among the objects of nature. Her imagination, in a somewhat grisly manner, invents a harvest of armed enemies - albeit imaginary enemies transformed from objects in nature to imaginary people she despises. Unlike her mother, who always keeps silent when the townspeople attack or condemn the family, Pearl "screamed and shouted, too, with a terrific volume of sound, which doubtless caused the heart of the fugitives to quake within them" (Hawthorne, Pennell ed., 2018, p. 124).

The absence of a father, in this lonely family unity, also produces an understandably negative impact on Pearl. As might be expected, Pearl's lack of normal parental supervision and involvement has great effect on Pearl. Often lack of parental functions leads to problem behaviors such as aggression, and violence (Stormshak, 2011, p. 209) The deficit in parental management often serves as a key determinant of problem behavior. A child needs closeness, engagement and warm praise. Several times in Hawthorne's work, Pearl craves her father's acknowledgement and recognition in public but finds her normal wishes refused. "Wilt thou stand here with mother and me, tomorrow noontide?" "Nay; not so, my little Pearl". "Not then, Pearl". "But another time." (Hawthorne, Pennell ed., 2018, p. 165). We can only speculate how this affects her psychological development.

Lack of familial and social support from peers, combined with the abuse and mistreatment by the community, and her father's refusal of public recognition all lead to Pearl's disconnect with the social environment and her unstable personality. Luckily, Pearl has her mother's unwavering love and also the company of nature, which enable her to grow up with a kind of happiness.

\section{The Healing Power of Nature and Love}

The understanding that nature can heal has existed among our species for millennia (Frumkin, 2013, cited in Kaufman, 2018). The natural environment can often serve suffering individuals as a fundamental source of wellness. According to some ecologists, nature acts on the mind-body by promoting a relaxation response while simultaneously focusing attention in a gentle and positive manner (Kaufman, 2018).

Due to Pearl's lack of validation by both the community and her father, Pearl lives largely in isolation and develops a strange personality. Fortunately, her time in the woods and outside by herself amongst the animals and natural world supports her, aids her, gives her a sense of happiness and belonging and prevents her from a deep mental breakdown. When Pearl is a little girl, she has no friends other than natural objects. Pearl "communicated itself to a thousand objects, as a torch kindles a flame wherever it may be applied" (Hawthorne, Pennell ed., 2018, p. 118). With her imaginative friends, and her freedom to live in her imaginary worlds, she does not feel overwhelmed or destroyed by loneliness.

Her imaginary world located in the freedom of the outdoors helps Pearl establish and maintain inner balance and peace, which is essential to her happiness. The diverse plants and animals, through the bird and insect sounds 
help Pearl merge with space in a more connected state, where the line between the objective physical world and her inner imagination remains porous.

It is in nature, in the loud harmony of birds, insects making their calls; and the roar of waves that Pearl finds tranquility, restoration and relaxation. We notice this process when we read, "A pigeon, alone on a low branch, allowed Pearl to come beneath, and uttered a sound as much of greeting as alarm. A squirrel, from the lofty depth of his domestic tree, chattered either in anger or merriment" (Hawthorne, Pennell ed., 2018, p. 202). In nature, Pearl lives as a loved and cherished little princess, "The flowers appeared to know it; and one and another whispered, as she passed, 'adorn thyself with me, thou beautiful child, adorn thyself with me!" (Hawthorne, Pennell ed., 2018, p. 203). Pearl takes the imaginary advice in her head to use simple flowers to adorn herself. It is in nature that her mind and body integrate as a whole and she finds love and peace. She gains, through her solitary walks in nature, restoration and healing from the environment.

Her mother's selfless, unconditional and unshakable love also serves Pearl's development and salvation. When Pearl is just a baby, her mother spends her meager income on decorating Pearl's clothes fancifully. When the authorities try to deprive Hester of her right to raise the child, Hester fights firmly. Pearl serves as all of Hester's happiness as well as her torture. Hester successfully fights to defend maintaining care for Pearl. At the end of the story, Dimmesdale's confession and acceptance of Pearl in public allows Pearl a sense of becoming a normal child who no longer needs to battle with the world. "A spell was broken. The great scene of grief, in which the wild infant bore a part, had developed all her sympathies; and as her tears fell upon her father's cheek, they were the pledge that she would grow up amid human joy and sorrow, nor for ever do battle with the world, but be a woman in it" (Hawthorne, Pennell ed., 2018, p. 240). Eventually, the power of nature and love heals Pearl, helping her breach her defense mechanisms and find interconnection with the human world and further expand her awareness and presence.

Nature, wildness, and love also heal Hester and Dimmesdale in a certain period. In the beginning of the novel, the symbolic nature image of the "wild rosebush" is out of place in the dark colors of the Puritan world. The wildness and beauty of the rosebush is a "token that the deep heart of nature could pity and be kind to the prisoner entering the structure" (Van Kirk, 2000, p. 17). After many years of suffering, in the wildness of the forest, Hester and Dimmesdale remove their camouflage and are true to themselves and their love. It is in the forest that Hester takes away the fastened scarlet letter and throws it among the withered leaves. She again finds her soft heart of womanhood and her youth and the whole richness of her beauty comes back. Love and nature's sympathy bless the two spirits and fill their hearts with radiance. Exposure to the forest can change the way people perceive themselves and the world around them.

In nature, people may look at the world from a different perspective with fresh eyes. "He could feel a more realistic view of one human being's place in the Universe. We are small, very small but we are part of something quite beautiful, something elegant in its wholeness and in the way things were interconnected and interdependent... In one way or another, everything is connected to something else, everything is valuable and of use to something, so there is no alienation in wild nature" (Geity, 1998, p. 4).

Nature and love endow the protagonists the ability to connect and integrate, giving them the sense of completeness at certain moments. Nature and love play essential roles in healing them. Only in nature and love can they find relaxation and a sense of belonging.

\section{Conclusion}

Literary works provide people the materials to discover the relationship between human behavior and their social and natural environment. Disconnection with the environment causes trauma, alienation and depression in people and deeply affects their mental health and well-being. Thus, strengthening family ties and community relationships to promote the sense of belonging and mutuality among the residents is essential as "individuals should be interdependent with their communities to the mutual benefit of both (Jeger \& Slotnick, 1982, p. 12).

People need intimacy, diversity, usefulness and the sense of belonging to keep their mental balance. Thus, the harmony between them and their environment, both external and internal, both natural and man-made is crucially important. Children should not bear the burden of their parents' sin, and revenge is never fruitful as it does not only ruin "the enemy", but also oneself. Only nature, love and interconnection with environment can heal.

\section{Acknowledgment}

I feel grateful to my country China, and my school, Zhengzhou University of Aeronautics. Without their support and sponsor, I would not have the chance to study in America as a visiting scholar for one year to do this research. I also owe a debt of gratitude to my supervisor, Dr. Yongkang Wei, who gives me constant guidance 
during my study, and my friend Dr. David Anshen, Professor Mimosa Stephenson, and Sarah, who help me a lot in revising my paper.

\section{References}

Becker, E. (1971). The Birth and Death of Meaning: An Interdisciplinary Perspective on the Problem of Man (2d ed.). Free Press.

Berger, R., \& Maya, T. (2012). The Enchanting Forest and the Healing sand-Nature Therapy with People Coping with Psychiatric Difficulties. The Arts in Psychotherapy, 39, 412-416. https://doi.org/10.1016/j.aip.2012.03.009

Chen, Y. C. (2017). On Arthur Dimmesdale's Double Personalities as Revealed in Hawthorne's The Scarlet Letter. English Language and Literature Studies. English Language and Literature Studies, 7(3), 85. https://doi.org/10.5539/ells.v7n3p85

Downey, G., \& Jarrell, E. D. (2020). The Dynamic Ecology of Rejection and Acceptance: Mental Health Implications. Archives of Sexual Behavior, 49, 2269-2273. https://doi.org/10.1007/s10508-020-01636-8

Escobar, A. (2008). Nature's Due: Healing Our Fragmented Culture Development. Development, 51, 154-159. https://doi.org/10.1057/palgrave.development.1100456

Freisthler, B. et al. (2006). Understanding the Ecology of Child Maltreatment: A Review of the Literature and Directions for Future Research. Child Maltreatment, 11, 263-280. https://doi.org/10.1177/1077559506289524

Gerity, L. A. (1998). The Healing Garden; Art and Nature. Canadian Art Therapy Association Journal, 12, 2-10. https://doi.org/10.1080/08322473.1998.11432232

Harper, P. (2000). Puritan Works Salvation and the Quest for Community in the Scarlet Letter. Theology Today, 57, 51-65. https://doi.org/10.1177/004057360005700105

Jay, C. (2015). The Healing Power of Nature. Bereavement Care, 34, 4-5. https://doi.org/10.1080/02682621.2015.1028195

Jeger, A. M., \& Robert, S. S. (1982). Community Mental Health and Behavioral-Ecology: A Handbook of Theory, Research, and Practice. Plenum Press. https://doi.org/10.1007/978-1-4613-3356-2

Kaufman, J. A. (2018). Nature, Mind, and Medicine: A Model for Mind-Body Healing. Explore, 14, 268-276. https://doi.org/10.1016/j.explore.2018.01.001

Kaul, A. N. (1968). Character and Motive in The Scarlet Letter. Critical Quarterly, 10, 373-384. https://doi.org/10.1111/j.1467-8705.1968.tb02002.x

Kilborne, B. (2005). Shame Conflicts and Tragedy in the Scarlet Letter. Journal of the American Psychoanalytic Association, 53, 465-483. https://doi.org/10.1177/00030651050530021601

Miller, K. E., \& Rasco, L. M. (2004). The Mental Health of Refugees Ecological Approaches to Healing and Adaptation. Mahwah, NJ: Lawrence Erlbaum. https://doi.org/10.4324/9781410610263

Myers, Z. (2020). Wildness and Wellbeing Nature. Neuroscience, and Urban Design. Springer Singapore. https://doi.org/10.1007/978-981-32-9923-8

Nutsford, D. et al. (2013). An Ecological Study Investigating the Association Between Access to Urban Green Space and Mental Health. Public Health, 127, 1005-1011. https://doi.org/10.1016/j.puhe.2013.08.016

Pennell, M. M. (2018). The Historian's Scarlet Letter: Reading Nathaniel Hawthorne's Masterpiece as Social and Cultural History. Praeger.

Shakuto, S. (2017). Japanese Tree Burial: Ecology, Kinship and the Culture of Death. The Asia Pacific Journal of Anthropology, 18, 95-97. https://doi.org/10.1080/14442213.2016.1162126

Snyder, G. (2004). Ecology, Literature and the New World Disorder. Irish Pages, 2, 19-31. https://doi.org/10.1093/isle/11.1.1

Stormshak, E. A. et al. (2011). An Ecological Approach to Promoting Early Adolescent Mental Health and Social Adaptation: Family-Centered Intervention in Public Middle Schools. Child Development, 82, 209-225. https://doi.org/10.1111/j.1467-8624.2010.01551.x

Tucker, K., \& John, Z. (2018). Gathered Remains: Essays on Wildness, Domestication, Community, and Resistance. Black and Green Press. 
Van Kirk, S. (2000). CliffsNotes on Hawthorne's The Scarlet Letter. Foster City. CA: IDG Books Worldwide.

Waldron, K. E., \& Rob, F. (2013). Toward a Literary Ecology: Places and Spaces in American Literature. Scarecrow Press.

Wang, Y. M. (2017). Misogyny or Feminism? A Probe into Hawthorne and His the Scarlet Letter. English Language and Literature Studies, 7(2), 139. https://doi.org/10.5539/ells.v7n2p139

Whitaker, A. (1999). Happiness and the Healing Power of Nature. Self \& Society, 27, 40-41. https://doi.org/10.1080/03060497.1999.11085981

Zapf, H. (2016). Literature as Cultural Ecology: Sustainable Texts. Bloomsbury. https://doi.org/10.5040/9781474274685

\section{Copyrights}

Copyright for this article is retained by the author, with first publication rights granted to the journal.

This is an open-access article distributed under the terms and conditions of the Creative Commons Attribution license (http://creativecommons.org/licenses/by/4.0/). 